This is an Author's Accepted Manuscript of an article published in European Security, vol. 22, no.2 (2013), 230-247 (copyright Taylor \& Francis), available online at:

http://www.tandfonline.com/doi/abs/10.1080/09662839.2012.727184\#.VKvVt3tAbSM

\title{
Green consumer markets in the fight against climate change
}

\author{
Elke Krahmann
}

\begin{abstract}
Climate change has become one of the greatest threats to environmental security, as attested by the growing frequency of severe flooding and storms, extreme temperatures and droughts. Accordingly, the European Union's (EU) 6th Environment Action Programme (2010) lists tackling climate change as its first priority. A key aim of the $\mathrm{EU}$ has been to cut $\mathrm{CO}_{2}$ emissions, a major factor in climate change, by 8 per cent until 2012 and 20 per cent until 2020. The European Commission has proposed the encouragement of private consumer market for green products and services as one of several solutions to this problem. However, existing research suggests that the market share of these products has been only 3 per cent, although 30 per cent of individuals favour environmental and ethical goods. This article uses Public Goods Theory to explain why the contribution of the green consumer market to fighting climate change has been and possibly may remain limited without further public intervention.
\end{abstract}

Keywords: environmental security; Public Goods Theory; climate change

\section{Introduction}

Environmental security has been recognised as a key area of concern in Europe, with climate change being the most pressing issue and motivation that requires both global and intra-European action (Jordan 2010). This is reflected in recent strategy papers and the 2008 review of the European Security Strategy (EU 2008a, 2008b). In particular, the European Union's (EU) Action against Climate Change report observes that climate change will 'have serious regional and global security implications' (European Commission 2009). In addition to the flooding of coastal areas, the spread of diseases borne by ticks and mosquitoes, and higher mortality rates due to heat waves, water scarcity and air pollution are presenting serious threats to the internal security of Europe. To address these threats, the EU is investing increasing resources and efforts in mechanisms for civil protection and disaster management (see Boin et al. in this special issue). However, a preventive approach would be even more desirable and effective. For this reason, the EU has adopted a wide-ranging programme of measures designed to reduce greenhouse gas emissions and to limit the effects of global warming.

Public Goods Theory has been critical to analyse the promises and pitfalls of international or global collective action with regard to highly diffuse and non-excludable goods such as climate security (Arrow 2007, Barrett 2007). Due to its [231] potential as a model for global cooperation, the EU's Emission Trading Scheme (ETS) has been a particular focus (Ellerman et al. 2010). However, sectors not covered by the ETS 'such as transport (except aviation), buildings and households, agriculture and waste still account for almost $60 \%$ of the EU's overall emissions' (European Commission 2009, p. 12). Since these emissions are more decentralised than those caused by industrial and energy production another set of $\mathrm{EU}$ policies aims to reduce $\mathrm{CO}_{2}$ emissions by encouraging the increased supply and consumption of 'green' technologies, products and services by private actors and consumers. Reducing private consumption may have the added benefit of increasing energy security within Europe by cutting demand for fossil fuels from problematic Third Country suppliers.

This article's focus on private actors and consumers raises interesting questions with regard to the role of European citizens as the supposed beneficiaries of internal security in the EU. While classic Public Goods Theory has mostly investigated whether and how much citizens are willing to pay for 
public goods such as national defence, similar questions now need to be extended to a wide range of other public security concerns, such as environmental security. The classic solution to such collective action problems are mandatory taxes, like fuel tax and environmental regulations. However, public protests and opposition by interest groups as well as the indirect and long-term effects of climate change limit the extent to which enforced contributions to public good production, or bad avoidance, can be levied (Jagers and Hammar 2009). As an alternative, voluntary, decentralised and incentivebased approaches could encourage both public and private actors to reduce their greenhouse gas emissions (Ostrom 2012). While the ETS is effectively a mandatory cost born by European industry and consumers, this article investigates whether voluntary consumer preferences can also be mobilised for the purposes of achieving environmental security.

The belief that the private consumer market has a role to play in the fight against climate change is widely shared among Western governments and international organisations (Maniates 2001, Princen et al. 2002, Kent 2009, Dauvergne 2010). Yet, the transition towards a low-carbon consumer market has progressed only slowly. One problem has been the so-called 30:3-syndrome. It refers to the observation that, although 30 per cent of individuals favour environmental and ethical goods, their market share has been only 3 per cent (Hobson 2004, Lane and Potter 2007). Numerous studies have investigated the gap between consumer attitude and action, observing that many factors can have a negative influence on green consumption, including lack of information, cost and habit (Roberts 1996, Berglund and Matti 2006). One aspect that has been less extensively researched is the supply of these goods (Lovell 2005). The question of whether there are any inherent impediments to the commodification of the fight against climate change for a private consumer market would benefit from further investigation.

The literature on the commodification of security, in general, and climate change, in particular, has been ambiguous in its assessments of market solutions. On private security, criticisms have included the changing conceptualisation of security, the rise of risk management and exaggeration of risk perception by private businesses (Loader 1999, Leander 2005, Krahmann 2011). With respect to climate change policies some authors have pointed out the implicit 'carbon colonialism' of ETSs set up by the EU and the Kyoto Protocol (Bachram 2004, Bumpus and Liverman 2008, [232] Lohmann 2009). Others have highlighted the dangers of commodifying nature and climate change because it allows businesses to profit from environmental problems (Castree 2003, Prudham 2009, Newell and Paterson 2010). A significant literature has challenged, in principle, the responsibilisation of the individual consumer for cutting $\mathrm{CO}_{2}$ emissions, arguing that it detracts attention from the need for broader political solutions (Princen et al. 2002).

This article seeks to contribute to the preceding debates by examining how Public Goods Theory (Stretton and Orchard 1994, Cornes and Sandler 1996) can help explain the problems of creating a European consumer market which supports reducing the threat of climate change and enhances the security of European citizens. In the context of this special issue, the following analysis also demonstrates how Public Goods Theory can be fruitfully used to analyse the wide range of security issues that are of concern today. Environmental security has arguably moved to the forefront of policy debates as the consequences of climate change have increasingly been felt not only in drought and conflict ridden Africa, but also in Europe.

Public Goods Theory has been widely used to understand security, environmental and $\mathrm{CO}_{2}$ emissions markets, but this article suggests that it has been underutilised in analysing the role of private consumers in the EU with regard to the management of greenhouse gas emissions (Mendez 1999, Krahmann 2008, Chichilnisky and Heal 2000, Stern 2007,). Public Goods Theory can offer several new insights into the business of fighting climate change. First, it provides a novel explanation for the small size of the consumer market for emission-reducing products by investigating their supply. Second, Public Goods Theory suggests that the limited size of the market for low-carbon goods and services is not only attributable to consumers and the industry, but also a consequence of the characteristics of certain products. It argues that inherent features make some goods and services unsuitable for market supply. Third, following from the preceding argument, this article illustrates why public intervention into the low-carbon consumer market has been and continues to be necessary to overcome these problems. Indeed, it shows that in some instances commodification, defined in this 
article as the transformation of a good into products or services for sale, has been possible only on the basis of frameworks established by the EU or national governments.

To investigate the role of product characteristics in delimiting their provision for a consumer market, this article examines three types of low-carbon goods and services: green cars, renewable electricity and carbon offset schemes. They were selected for two main reasons. The first reason is that each of these products represents a particular type of good as defined by Public Goods Theory. The second is that energy consumption ( 27 per cent) and transport (20 per cent) are the top sources of domestic $\mathrm{CO}_{2}$ emissions in the EU, suggesting that product changes or offsets in these sectors may have significant impacts (Boardman 2007, p. 11, Department of Transport 2009, p. 3).

\section{Commodifying climate change}

Public Goods Theory seeks to explain what goods and services businesses are likely to offer for sale and what kinds have to be supplied by the state. To do so, Public Goods Theory distinguishes goods in terms of two characteristics pertaining to the benefits of a product or service. One is excludability, i.e. the ability to exclude [233] potential consumers from a good. Examples of excludable goods are cars or houses which typically belong to individual consumers who are their only beneficiaries or who are able to control who else may use them. Non-excludable goods, by contrast, are free for the taking such as fresh air or rainwater. The other feature is rivalry, i.e. whether the benefits of a good are reduced by consumption. The more consumers a rival good has the fewer are its benefits for each. The more people share a loaf of bread, for instance, the less there is to eat for each. Non-rival goods and services retain the same benefits irrespective of how many consumers there are. TV broadcasting is a non-rival good because it has the same quality irrespective of the number of viewers.

Based on these two dimensions, Public Goods Theory distinguishes between four ideal-types of goods. First, 'private goods' are both excludable and rival such as washing powder or roller skates. Second, 'club goods' are excludable, but non-rival. They are termed 'club' goods because they benefit a limited group of users such as databases or computer programmes. Third, 'common pool goods' are non-excludable, but rival. Common pool goods typically occur in nature such as fishing and hunting grounds. Fourth, 'public goods' are both non-excludable and non-rival. Examples mentioned in the literature include national security, traffic lights and lighthouses (Kaul et al. 1999, pp. 2 27).

As these categories are ideal-types, there few examples of 'pure' goods. Frequently it is possible to find exceptions or limitations such as national claims to coastal waters in the example of fishing grounds. Moreover, the conceptualisation of a good can affect its categorisation and its ability to be commodified. Security, for instance, can be understood as prevention, deterrence, protection or resilience to threats (Krahmann 2011). Each has different characteristics in terms of its excludability and rivalry, thus making some security services more suitable for private market provision than others. Finally, a good or service can have multiple benefits which may material as well as ideational, thus complicating their categorisation.

Nevertheless, these ideal types help to explain why some goods can be commodified more easily than others. According to Public Goods Theory, there are two parts to this explanation. First, most people are primarily interested in material benefits. Second, most people are only willing to pay for benefits that are excludable. If the same benefits could be had for free, they would not need to buy them. The tendency of consumers to free-ride on non-excludable goods suggests that profit-oriented companies are unlikely to produce and supply such goods for the private market. In these cases the state has to step in. Commercial businesses are also likely to favour rival goods because they are consumed and have to be reproduced. In short, businesses are most likely to produce private goods and least likely to supply public goods.

From the perspective of Public Goods Theory the commercial production of goods and services which contribute to cutting $\mathrm{CO}_{2}$ emissions presents a puzzle because fighting climate change appears to approximate a pure public good. ${ }^{1}$ The effects of fighting climate change are both non-excludable and non-rival. Nobody can be excluded from the impact that lowering carbon emissions may have on the global climate, and the effects of fighting climate change are not reduced by an increase in the number of people who are exposed to it. Of course, it does not mean that there are only benefits to 
fighting climate change or that its effects are [234] distributed equally, but this is not necessary to define a good as a 'public' good (O'Brien and Leichenko 2000). The key is that the one overriding benefit of fighting climate change, namely giving people time to adapt, is both non-excludable and non-rival [Intergovernmental Panel on Climate Change (IPCC) 2008, p. 5, 82]. Unfortunately, as nobody can be excluded from this benefit, fighting climate change is prone to free-riding. Countries and citizens may support the call for action, but they are likely to resist carrying the cost, as demonstrated by the Kyoto Protocol. The sale of products which help to fight climate change to individual consumers should be similarly difficult. Nevertheless, the past few years have witnessed the emergence and proliferation of specific products and services which claim to reduce greenhouse gas emissions. Although their market size remains small, the question that arises is: how can businesses commodify the fight against climate change if it has the features of a public good?

A preliminary survey of the types of goods and services offered under the low-carbon label suggests an answer. Private firms offer few pure public goods (Kotchen and Moore 2005). Instead, most of the goods and services sold to reduce greenhouse gas emissions provide a mixture of public and private benefits. If one tries to fit them into the ideal-types proposed by Public Goods Theory, they appear to fall into three categories. The first category includes conventional products with reduced emissions, such as energy efficient cars and refrigerators or food from local farms. These products are best defined as impure private goods since most of their primary benefits are excludable and rival. In the cases listed above, private benefits include a flexible means of transport, the preservation of food and the taste of fresh vegetables. Only secondarily do these products have public benefits through their reduction of greenhouse gas emissions. In the second category of products, public and private benefits are the same, or at least, directly linked. They include technologies and practices such as double glazing and insulation, solar and wind energy, and energy efficiency consulting which ensure lower energy consumption and thus cut household bills. This category can be conceived of as impure public goods since a primary aim is lower emissions, but this also has direct private benefits. The third category regards goods which have the sole purpose of lowering greenhouse gases such as carbon-offset schemes or donations. Since their primary benefit, slowing climate change, is non-excludable and non-rival, they can be considered the approximation of a pure public good. One reason why they can still be sold to private consumers appears to be that a small group of consumers is willing to pay for excludable ideational benefits such as the 'warm glow' of altruism (Andreoni 1990).

There are many ways of combining public and private benefits in practice. Some companies offer conventional products which include a small donation. A typical illustration is carbon offsetting included in the cost for flight tickets or green holiday packages. Other goods seem to fall between the first and second categories such as recycling products. Recycling plays a major part in reducing emissions, but recycled products such as toilet paper or glass are bought largely for their private use value. Nevertheless, the preceding distinctions help illuminate some of the features of the consumer market for low-carbon products. Public Goods Theory explains, for instance, why firms may be interested in combining public and private benefits. Moreover, as the case of carbon offsets will show, customers seem more willing to pay for a public good if it is marketed like a private good.

[235] Given the limited scope of this article, it focuses on three examples to illustrate the categories of goods outlined above: green cars, renewable energy and private carbon offsetting. Moreover, due to the size of the EU consumer market it focuses on the UK as an illustrative example because British governments have been very supportive of market approaches towards fighting climate change (HM Government 2008). Already in the 1990s the Labour government attempted to link economic growth, environmental protection and resource development through the concept of sustainable consumption (Hobson 2004, Seyfang 2005). Arguing against 'prescriptive changes' to business practices, the government contended that market-friendly policies could lead to a win-win situation in which businesses and the environment would benefit from the development of new low-carbon products and services (Hobson 2004, p. 124, HM Government 2011).

\section{Low-carbon products}

In order to assess the role that businesses may play in lowering $\mathrm{CO}_{2}$ emissions by turning the fight 
against climate change into products for sale this section examines three questions: First, how can firms convert combating climate change by reducing $\mathrm{CO}_{2}$ emissions into products and services for sale to private consumers? Second, what strategies do companies use to market low-carbon products and services? Third, what has been the contribution of the private consumer market to fighting climate change and what have been its limitations?

\section{Green cars}

Passenger cars make up 12 per cent of the EU's total $\mathrm{CO}_{2}$ discharge, and transport is the second largest source of private household emissions in the UK (Department of Energy and Climate Change 2009, Department of Transport 2009, p. 3). For this reason, the EU adopted a 'comprehensive new strategy to reduce carbon dioxide emissions from new cars and vans sold in the European Union' in 2007 (European Commission 2010a). On the supply side, the strategy encouraged voluntary commitments by the European (ACEA), Japanese (JAMA) and Korean (KAMA) car manufacturers associations to reduce the average new car emission to $140 \mathrm{~g} / \mathrm{CO}_{2} / \mathrm{km}$ by 2008 (ACEA) and 2009 (JAMA, KAMA), respectively. On the demand side, it proscribed the introduction of fuel economy labels for cars to be displayed at 'point of sale' in order to inform consumer choice and demanded that national vehicle taxation was linked to $\mathrm{CO}_{2}$ discharge. Despite these efforts, total $\mathrm{CO}_{2}$ emissions from private vehicles have continued to increase in the EU, generally, and the UK, specifically (Department of Transport 2009). What has hindered the development of a European market for 'green' passenger cars? So far this question has been explored primarily in terms of impediments to the technological development of low-emission cars and the limited consumer demand for such vehicles (e.g. Paterson 2000). This section suggests that Public Goods Theory may offer another explanation by focusing on the inherent limitations of a market for green passenger cars.

Before this question can be answered, however, it is necessary to understand what makes a 'green' passenger car. The definitions of green light-duty vehicles differ widely between the expert literature, the EU Commission, national governments, the automobile industry and the media. Experts speak of low-carbon cars with regard to [236] automobiles emitting less than $100 \mathrm{~g} \mathrm{CO}_{2}$ per kilometre $(\mathrm{km})$ (Lane and Potter 2007, p. 1085). Accordingly, the British government excludes cars meeting this standard from vehicle tax under the UK Vehicle Excise Duty (VED) scheme introduced in 2001 which links the amount of tax payable for private vehicles to types of fuel and levels of $\mathrm{CO}_{2}$ discharge. To help prospective vehicle buyers and in line with EU policies, the British government also encouraged the voluntary introduction of a label for 'Fuel Economy' in collaboration between the automobile industry and the Low-Carbon Vehicle Partnership. However, these demand-side policies have had severe limitations because of divergent definitions of what makes a 'green' car. In particular, the British Fuel Economy label is confusing rather than helpful for the uniformed consumer. First, while fuel economy relates to miles per gallon (MPG) or litres per $100 \mathrm{~km}$, the industry label refers to carbon dioxide emissions. Second, in contrast to the expert definition cited above the label marks, literally, as 'green' all cars which produce less than $150 \mathrm{~g} \mathrm{CO}_{2} / \mathrm{km}$. Third, the label uses the same alphabetical labels for $\mathrm{CO}_{2}$ emission categories as the VED tax scheme, but its units are different. Thus, the label that refers to emissions of $141-150 \mathrm{~g} \mathrm{CO}_{2}$ is coloured light green, despite having a higher VED than the lower two tax bands which have the same fuel economy label colour.

Because of the absence of an agreed definition of a low-carbon passenger vehicle in the EU and the UK, this section examines all models which are either framed in such a way by automobile producers or emit less than the EU's target of $140 \mathrm{~g} \mathrm{CO}_{2} / \mathrm{km}$. Since the total market is too large for a comprehensive analysis, the following focuses specifically on the five automobile manufacturers which had the largest market shares in the UK in 2009: ${ }^{2}$ Ford (17 per cent), Vauxhaull (14 per cent), Volkswagen ( 8 per cent), Toyota ( 5 per cent) and Audi (5 per cent) (The Society of Motor Manufacturers and Traders 2009). All but Audi had an explicitly 'green' vehicle range. ${ }^{3}$ However, with the sole exception of Toyota's Prius all models had conventional petrol and diesel motors. They achieved fuel efficiency and lower carbon emissions by means of minor technical adjustments, such as improved aerodynamics, fuel efficient engines, low weight, low rolling resistance tyres, low-viscosity transmission oil and diesel particulate filters. Only the Ford Fiesta ECOnetic and the Volkswagen Polo BlueMotion had $\mathrm{CO}_{2}$ emissions below $100 \mathrm{~g} / \mathrm{km}$. Both models had diesel engines. The remaining models had emissions between 100 and $159 \mathrm{~g} / \mathrm{km}$. 
These findings show that the supply of low-emission cars in the UK has been rather limited. Moreover, many cars that were labelled 'environmentally friendly' did not contribute significantly to lowering $\mathrm{CO}_{2}$ emissions since the average new private vehicle's emission in the EU, including noneco models, was already $146 \mathrm{~g} / \mathrm{km}$ in 2009 . The most widely available 'low-emission' models were still far from the European Commission target of an average of $95 \mathrm{~g} / \mathrm{km}$ for the year 2020. In order to achieve this aim radical technical innovations are necessary, such as the move to hybrid or electric cars. The four main UK automobile companies offered no such products. New developments are and have been in the pipeline for years, but even in 2011 they still had not reached the sales shops. In sum, supply can be considered a major factor in the limited size of the green car market.

Turing to $\mathrm{CO}_{2}$ emissions as a marketing device for car manufacturers, the findings are similar. On most websites, green models did not feature prominently. The potential consumer had to search specifically for low-carbon cars in order to be [237] directed to the relevant pages. Neither did the companies use the voluntary Fuel Economy label to promote their products. Most websites used instead the VED tax bands as a promotion device because they refer to tax savings, which have excludable benefits for prospective buyers. The benefits for the environment and the fight against climate change were considered secondary. Companies explicitly emphasised that they pursued environmental benefits only as far 'as possible today, without compromising your driving experience'. ${ }^{4}$ Companies also often portrayed radically new inventions in a negative light, arguing that advantages could be found in an 'intelligent refinement of existing technology', while more extensive innovations were described as 'different', 'expensive' and 'bolted on'.5

Public Goods Theory helps to explain both the limited supply of low-carbon vehicles and the failure to market them as such. It suggests that a key factor is the unwillingness of most consumers to pay for additional technological improvements which do not provide them with excludable, private benefits. As a result manufacturers find it problematic to pass on the cost for the new development of vehicles which meet the EU target of $95 \mathrm{~g} / \mathrm{km}$. Government taxation linked to $\mathrm{CO}_{2}$ emission levels tries to overcome this issue by cutting the running cost of 'green' vehicles. However, apparently it is not sufficient to offset the higher investment cost of buying a car with significantly lower emissions such as hybrid-cars or the inconvenience of a smaller model.

Also the marketing of passenger cars illustrates the importance of excludable benefits in the supply of green cars. Fuel expenditure and tax savings are mentioned foremost as selling points, followed by 'fun' and 'driving experience' (Pattie and Crane 2005). Obviously there is a direct relationship between fuel consumption and $\mathrm{CO}_{2}$ emissions. Reduced spending on petrol could thus provide an excludable benefit which could be utilised to encourage consumers to buy 'green' vehicles and contribute to the public good. However, because lower fuel consumption is so far negatively related to other private benefits such as car size, motor power and range, there are inherent limits to creating a 'win-win' situation for the environment and the consumer based on cars with a higher MPG ratio. In addition, car producers are seeking to restrict their investment cost by making minor changes to existing models. The EU's 2007 Strategy unfortunately supported this approach by suggesting legislative measures in the member states related to 'the compulsory fitting of accurate tyre pressure monitoring systems; setting maximum tyre rolling resistance limits . . .; the use of gear shift indicators' rather than policies which pushed the manufacturers towards more radical innovations such as hybrid motors (European Commission 2010a, p. 4). The next section shows that the start up cost of new technologies can, nevertheless, be overcome by manufacturers and new profitable markets created if there is a stronger link between private consumer benefits and lower carbon emissions.

\section{Renewable energy}

According to EU studies 'the greatest potential for emissions reductions comes from the electricity sector' (European Commission 2010b, p. 9). Households are major consumers of electricity, mainly for heating. In the UK private household energy consumption, thus, accounted for 27 per cent of $\mathrm{CO}_{2}$ emissions (Boardman 2007). Nearly 90 per cent of primary energy production in the UK derives from carbon [238] sources such as oil, gas and coal. The supply of renewable energy such as solar energy, hydropower and wind has increased only minimally, reaching 6.8 per cent of British electricity production in 2010 (Department of Energy and Climate Change 2010). It has remained woefully short of the target of 20 per cent by 2010 set by the UK government in 1998; but it seems on track for the national target of 15 per cent by 2020, which was agreed with the EU in 2009. 
Academic research has sought to explain this failure in terms of two factors: governmental policies and customer demand (Wüstenhagen and Bilharz 2006, Toke and Lauber 2007). This section investigates what role British energy companies have played in shaping the renewable energy market in the UK. Since there is no statistical data available about the number of renewable energy customers who subscribe to different companies in the UK, it analyses five suppliers which might reasonably be assumed to have had major green tariff market shares in 2009, namely British Gas, Scottish and Southern Electric (SSE), Ecotricity, Green Energy and Good Energy. The first two belong to the 'big six' UK energy companies, the latter three focus specifically on green energy.

Renewable energy forms one of the largest, but also one of the most confusing markets for environmental products and services in the UK. Already in 2009 nearly all British energy suppliers offered 'green' tariffs. These tariffs included one or several of the following elements: renewable electricity supply, 'green' energy funds and carbon offsets (Graham 2007, p. 7). The 'Zero Carbon' tariff by British Gas, for instance, provided electricity from 100 per cent renewable sources, a 100 per cent carbon offset of the customer's electricity consumption, and a contribution to its 'Energy for Tomorrow' fund which develops renewable energy generation. In addition, British Gas buys and 'retires', i.e. removes from the market, 12 per cent of Renewables Obligations Certificates (ROCs) issued by the UK government in order to encourage the supply of renewable energy. By comparison, SSE's 'Better Plan' tariff only supplied 100 per cent energy from renewable sources. Among the three smaller 'green' companies, Ecotricity offered two tariffs. 'New Energy' which supplied 50 per cent renewable energy from its own wind farms, plus 50 per cent conventional energy; and 'New Energy Plus' which bought an additional 50 per cent renewable energy from other suppliers to make up a package of 100 per cent renewables. Green Energy had no own sources of renewable energy, but offered two tariffs of 100 per cent green energy bought from smaller suppliers, often home producers. Finally, Good Energy had a single tariff of 100 per cent renewable energy from own sources and independent producers, which also included the retiring of 5 per cent ROCs over and above the government requirement of 9.1 per cent in $20089 .^{6}$

In order to help consumers find their way through the variety of 'green' tariffs, government watchdogs and non-governmental organisations (NGOs) working in the area provided basic comparative data on all UK energy suppliers. Despite this information, the contribution made by these tariffs to cutting $\mathrm{CO}_{2}$ emissions remained often diffuse and unclear. The complexity of the subject matter, and debates among experts and companies over the green credentials of their various approaches appear to undermine rather than encourage consumer confidence in the benefits of green electricity schemes. The greatest division is between those electricity suppliers who reinvest their profits into the building of new facilities for the production of renewable energy, and those who buy existing green electricity from individual suppliers and retire the ROCs issued by the UK government. A ROC is a [239] green certificate issued by the UK government to a generator of renewable electricity for each megawatt hour. Since the government set an obligation of at least 9.1 per cent (3 per cent in the northern Ireland) renewable energy production by licensed generators in 20089 , companies that did not produce enough renewable energy to meet this obligation either bought ROCs from those who produced more than they needed or paid into a buy-out fund.

The marketing strategies of green energy suppliers primarily appealed to private interests and benefits. The price of electricity was a key element. British Gas, SSE and Ecotricity emphasised that they did not charge significantly more for their green energy. British Gas and SSE also offered a free standby saver and electricity monitor to new customers. Green Energy attempted to attract consumers by making non-tradable company shares available to its first 100,000 clients. Somewhat counterproductively with regard to the aim of reducing $\mathrm{CO}_{2}$ emissions, British Gas and Ecotricity had lower prices per $\mathrm{kWh}$ with higher levels of consumption. Only SSE offered to reward customers who reduced their energy bill by 10 per cent from last years' bill. All green energy tariffs also claimed to contribute to a public good by lowering $\mathrm{CO}_{2}$ emissions. Only the companies which supply exclusively green energy such as Ecotricity, Green Energy and Good Energy tried actively to mobilise environmentally conscious consumers. They did so by engaging prospective and existing customers in the debate over renewable energy through blogs such as 'Zero Carbonista' by Ecotricity and a blog by Good Energy, information about climate change and energy saving measures, and detailed comparisons of the green credentials of various energy suppliers and their approaches. In short, the 
renewable energy market in the UK can be broadly divided between those companies which attempt to attract customers primarily through private benefits and those who focus on consumers who are concerned about fighting climate change.

Public Goods Theory helps to understand why there might be less supply problems with green energy tariffs than with low emission passenger vehicles. A key reason is the fact that there are no differences in private benefits between conventional and renewable energy. Whether electricity is derived from solar panels or coal power stations, it has the same use value to the consumer. Energy thus differs significantly from passenger cars which vary considerably in terms of size, convenience and driving experience. The cost of energy is the only private use factor differentiating between suppliers. At comparable cost, it is thus likely that renewable energy tariffs can generate sufficient consumer demand for a product which also provides public benefits in terms of reducing $\mathrm{CO}_{2}$ emissions.

Nevertheless, Public Goods Theory suggests that green energy suppliers and tariffs in the UK would still have struggled to compete with conventional energy as long as they had to recoup their start-up investments. Although renewable energy might in the long term be cheaper than electricity derived from coal, gas or nuclear power, the latter have been built, often with government subsidies, decades ago, giving them a major advantage. In this case the theory recommends government intervention in order to compensate for market 'failure'. Indeed, the policies of the UK government, specifically its compulsory renewable energy obligation and the ROC trading scheme, combined with increased oil and gas prices over the past years, have been critical in allowing companies to offer green tariffs which are not more expensive than electricity from conventional sources. The next section discusses in [240] the example of carbon offsets why public intervention is the more important the closer a product comes to being a 'pure' collective good.

\section{Carbon offsets}

Private household carbon offsetting has not, so far, been a focus of the EU policies. Nevertheless, several reasons justify the inclusion of carbon offsets in this analysis. First, carbon offsets for private consumers are offered by many companies across the EU, often international businesses such as airlines. Second, private carbon offsets pertain primarily to $\mathrm{CO}_{2}$ emissions from aviation, transport and electricity consumption, thus linking it to the most important areas of private consumer greenhouse gas emissions in Europe. Third, carbon offsetting is a service which comes closest to the ideal-type of a public good because its only material benefit is fighting climate change, thus raising the question of how it can be commodified.

The basic idea behind carbon offsetting is that greenhouse gas emissions from some sources can be cancelled out by cuts elsewhere. Although offsetting does not necessarily reduce emissions below existing levels, it at least helps to prevent further increases. The principle of emissions offsetting has been most prominently implemented by international institutions such as the Kyoto Protocol (Helm and Hepburn 2009, Paulsson 2009). However, studies attest that private consumer demand for carbon offsets has been growing (Brouwer et al. 2008, Lovell et al. 2009, MacKerron et al. 2009). Analytically, it is possible to distinguish between two types of private carbon offset markets. The first type has developed as a derivative of the international ETS and the Clean Development Mechanism (CDM) established under Article 12 of the Kyoto Protocol. In this case carbon offsetting companies buy emission credits from strictly monitored international programmes for emissions trading among states and sell them on to private clients. The CER credits, awarded to greenhouse gas cutting projects in developing countries under the CDM, are the most popular. They gained particular recognition in the UK through the 'Government Quality Assurance Scheme for Carbon Offsetting', which sought to indicate to consumers the respectability of particular offset schemes. ${ }^{7}$ The second type of market has evolved on the basis of voluntary credit systems certified by NGOs and directed primarily at corporations and individuals (Lovell et al. 2009, pp. 2361 2362).

This section examines the five companies and organisations which had been approved by the UK Government Quality Assurance Scheme for Carbon Offsetting by early 2009: British Airways, Carbon Footprint, Carbon Passport, Clear and PURE. ${ }^{8}$ Four of them are incorporated businesses; one (PURE) 
is a registered charity. Since the basis for the UK government accreditation is the sale of CERs rather than voluntary credits, the analysis is skewed towards the first type of emission markets. However, as the following analysis will show, some of these companies also offer other kinds of carbon offset schemes.

British Airways offered to offset personal $\mathrm{CO}_{2}$ emissions caused by flights with this airline. Carbon Footprint, Carbon Passport, Clear and PURE supplied offsets for personal emissions in six or five areas, including household, flight, car, motorbike, bus and rail and secondary emissions such as food, recycling, fashion, packaging and finance, over a period of time defined by the customer. All five providers bought UN certified CER credits to offset the $\mathrm{CO}_{2}$ emissions of their clients. The projects from which CER credits were obtained were clearly listed on [241] their websites and included typically projects from rapidly developing nations, such as wind farms, hydroelectric power plants and waste power plants in China, Brazil and India as well as reforestation projects in Kenya, the UK and Latin America.

The most striking feature of the marketing strategies used by the five providers was the privatisation and individualisation of carbon offsetting, despite the fact that offsetting provides essentially a public good. Several strategies helped to create the impression that providers were offering an excludable product or service. First, all providers went through considerable length to calculate their client's 'personal' carbon footprint for a specific time period, including emissions from cars, motorbikes, public transport, flights, heating and household appliances. Carbon Footprint and PURE even included the option to make deductions for 'responsible' consumption, such as the use of energy savings devices and recycling. Behind these detailed calculations is the notion that consumers need to pay for only as many CERs as are necessary to offset their own emissions. They thus disguised that the clients were in effect making a voluntary donation to the public good. Second, some companies offered consumers a choice among different CER projects or carbon reduction services. The clients of Carbon Footprint, for instance, could select to offset their personal $\mathrm{CO}_{2}$ emissions through either Reforestation in Kenya, VCS certified projects which supported clean energy, United Nations Environment Programme projects in the Americas, UK tree planting or CERs. Third, Carbon Footprint provided additional material benefits for its clients such as free site energy reduction surveys and free expert guides. Carbon Passport adopted another strategy by selling carbon offset 'gift certificates' for $£ 10, £ 20$, 'a gap year', 'a honeymoon', 'a year' or 'an around-the-world trip', thus turning carbon offsetting into a private good which one can give to another person. Only PURE implicitly acknowledged that private carbon offsetting is essentially a donation by allowing clients to decide how many CERs they wished to buy without a prior calculation of their carbon footprint.

As Public Goods Theory expects, the absence of significant material benefits for the private consumer is a problem for the development of a private carbon offset market. Without the creation of carbon certification schemes by national governments and international organisations this market would not exist at all. Further-more, private demand for carbon offsets is limited because it has little excludable benefits. The attempts of offset businesses and providers to link their offsetting services to private benefits such as certificates or, at a minimum, to create the impression of excludability through the personalised calculation of carbon footprints thus become understandable from the perspective of Public Goods Theory. The theory also explains why corporate clients are more likely to offset their $\mathrm{CO}_{2}$ emissions than households. For corporations the label of being 'carbon neutral' can have significant excludable benefits such as rising share prices and sales among environmentally conscious consumers. ${ }^{9}$ It is, therefore, unsurprising that corporations make up 80 per cent of the global market for voluntary carbon offsetting, while individuals only account for 5 per cent (Lovell et al. 2009).

\section{EU climate change policies}

Public Goods Theory helps to explain why interventions by the EU and its member states play a critical role in the creation of viable low-carbon consumer markets. [242] Specifically, it argues that products and services which link the public good of reducing $\mathrm{CO}_{2}$ emissions only indirectly to private benefits or where private use value even seems to be diminished by making products more environmentally friendly are unlikely to be spontaneously and effectively provided by private markets. Accordingly, the creation of a consumer market for low-carbon products and services has been most successful in the renewable energy sector where private benefits are not reduced by switching to green 
energy tariffs if these are not significantly more costly. The EU's renewable energy target for the UK of 15 per cent by 2020 has arguably provided a major incentive for the British Government to increase the pressure on energy producers to supply green electricity and the ROCs have helped to compensate for some of the price advantages that conventional energy suppliers had by using existing facilities. ${ }^{10}$

The market for green passenger cars, by comparison, has suffered from the weaknesses of EU and UK Government initiatives which have not adequately addressed the fact that lowering $\mathrm{CO}_{2}$ emissions seems to impact negatively on many of the private benefits of existing models. The EU's 2007 Strategy which built on voluntary commitments by the main car manufacturers' associations to reduce average $\mathrm{CO}_{2}$ emissions from new vehicles has clearly been unsuccessful as the agreed targets had not been reached. The EU's requirements for minor technical adjustments supported rather than challenged car producers' slow response to the call for greener vehicles. The EU and its member states appear to have realised this and have responded with new legislation which requires manufacturers to pay a penalty for each new car registered which does not meet the target of less than $130 \mathrm{~g} \mathrm{CO}_{2} / \mathrm{km}$ by 2015 (European Commission 2011). The target will be introduced progressively, rising from 75 per cent compliance in 2013 and 80 per cent in 2014 to 100 per cent in 2015. Whether this policy will be more successful remains to be seen. Since the costs for a penalty will be passed on to the consumer, it will help to address the current imbalance in the higher cost of some green models, such as hybrid vehicles, to conventional models. However, other private benefits such as the size and convenience of a car still play a major role in consumption behaviour and consumers may be willing to pay the oneoff fine for them if they can only be had with a higher emission vehicle. Public Goods Theory suggests that a better approach would be if the EU and its member states decided to strengthen the link between private and public benefits, e.g. through the existing connection between fuel consumption and $\mathrm{CO}_{2}$ emissions. It could be achieved by further increasing petrol prices and/or vehicle tax for high emission passenger cars. These measures would not only have a continuous effect on private cost-utility functions rising total cost progressively in line with emissions but also significantly increase government income which could be invested in low-carbon modes of transport.

The carbon offset market for private households has, so far, not been a target of EU policies. This is hardly surprising as the preceding analysis illustrates that the potential for an expansion of this market is rather limited because its service approaches a 'pure' public good. According to Public Goods Theory the only possibility for increasing the amount of private household offsets would be to turn them into emissions taxes levied on the consumption of particular goods and services, such as flights or heating. The EU has apparently reached a similar conclusion by deciding to include at least aviation into the ETS from 2012. Like other high emission industries 'airlines will receive tradeable allowances covering a [243] certain level of $\mathrm{CO}_{2}$ emissions from their flights per year. After each year operators must surrender a number of allowances equal to their actual emissions in that year', meaning that the flying cost for passengers will increase as airlines pass on the cost for buying additional allowances (European Commission 2008).

\section{Conclusion}

The promotion of green consumer markets has been one measure implemented by the EU to combat climate change and to reduce resulting threats to the security and well-being of European citizens. Nevertheless, the private consumer market for low-carbon products and services has remained small. Much of research has investigated the lack of demand for green products and services as well as the difficulties of translating consumer interest into consumption behaviour. This article has examined the supply-side of the equation. Building on Public Goods Theory, it has offered an explanation of why the supply of low-carbon consumer goods has been and is likely to remain limited without stronger public interventions. Several problems account for market failures. First, private businesses find it difficult to commodify a public good such as fighting climate change. Only where products and services which lead to emissions reductions can be linked directly to excludable material benefits for the individual consumer appears to be a potential for generating private demand. By contrast, the sale of products which approach a 'pure' public good such as carbon offsets appeals only to a very small audience concerned with ideational benefits such as the positive emotions associated with altruism. In fact, as this article has shown, even in these instances, many companies attempt to give public goods 
the appearance of private material benefits, e.g. by offering a choice among different offset projects and handing out offset 'certificates'. Second, sunk or start-up costs can prevent private businesses from investing into new technologies for the production of low-carbon goods because they expect that consumers will not pay for them. As the passenger vehicle industry illustrates, minor technological improvements have been preferred over radical innovations and voluntary commitments for producing lower emission vehicles have not been met. A greater potential appears to exist in areas where lowcarbon products lower the cost of production in the long term and, thus, the price for consumers, as with renewable energy. However, even in these cases, public intervention might be necessary to overcome the advantage of already established products and services. Other theoretical approaches might help to understand why this intervention has not always happened or why it has been limited.

In sum, Public Goods Theory helps to assess whether and to what degree the EU and member government policies are necessary to address market 'failure' to provide low-carbon products and services. As this article has demonstrated, goods which have the characteristics of a 'pure' public good such as household offsets either require public major intervention such as turning them into environmental taxes or are likely to remain marginal. By contrast, products and services which approach 'impure' public goods may be successfully commodified if private and public benefits are linked either due to the inherent characteristics of the product or through public policies. For further research, these findings may be compared to other areas of European security that strongly rely on the contribution of private actors and consumers, such as cybersecurity or critical infrastructure protection.

\section{Notes}

1. Some studies conceptualise the issue of climate change as an unintended cost, i.e. a negative externality to other public and private goods, or as a public 'bad'. See also the introduction to this issue. This article adopts a reverse psychology by viewing the fight against climate change as a positive good in order to explain its commodification rather than collective action problems.

2. This and the following sections present the supply of green cars, electricity and off-sets as of 2009, for which the latest EU statistics on $\mathrm{CO}_{\mathrm{s}}$ emissions were available at the time of writing. Follow-up research in 2011 shows that neither the range of cars and their $\mathrm{CO}_{2}$ emissions nor that of 'green' electricity schemes examined in the next section had changed significantly.

3. Ford 'ECOnetic' Series: Fiesta (98 g/km), Focus $(114-115 \mathrm{~g} / \mathrm{km})$ and Mondeo $(139 \mathrm{~g} / \mathrm{km})$; Vauxhall 'ecoFLEX' Series: Agila (119-120 g/km), Corsa $(105-119 \mathrm{~g} / \mathrm{km})$, Astra $(119 \mathrm{~g} / \mathrm{km})$, Zafira (139 g/km) and Insignia (136 g/km); Volkswagen 'Blue Motion' Series: Polo (99 g/km), Golf (127 g/km), Golf Estate (122 g/km), Jetta (122 g/km), Passat

(128 g/km), Touran (144 g/km), Sharan $2.0(159 \mathrm{~g} / \mathrm{km})$; Toyota Prius $(104 \mathrm{~g} / \mathrm{km})$, Aygo (108 $\mathrm{g} / \mathrm{km}$ ), Yaris (119 $136 \mathrm{~g} / \mathrm{km})$, Auris (131 g/km); Audi SE 1.4 TFSI (113 g/km); Audi SE and Standard 1.9TDIe engine $(119 \mathrm{~g} / \mathrm{km})$; Audi SE 2.0 TDI engine $(134 \mathrm{~g} / \mathrm{km})$.

4. See http://www.ford.co.uk/Cars/FordECOnetic; also Volkswagen, http://www.volkswagen. co.uk/volkswagen-world/environment/blue-motion

5. See http://www.volkswagen.co.uk/volkswagen-world/environment/blue-motion and http:// www.ford.co.uk/Cars/FordECOnetic

6. The government requirement increases every year and was set at 11.1 per cent in 201011 .

7. In 2011, it was replaced by the governmental 'Approved Carbon Offsetting' quality mark.

8. UK, government, Act on CO2, 'Offsetting', at: http://campaigns2.direct.gov.uk/actonco2/ home/features/offsetting.html [accessed 2009]. Since then four additional have been awarded the government's 'Approved Carbon Offsetting' mark, namely Carbon Retirement, The International Air Transport Association (IATA), TAP Portugal, EON and Buying Solutions. The latter is notable for being 'part of the Efficiency and Reform Group within the Cabinet Office'. See 
http://www.direct.gov.uk/en/Environmentandgreenerliving/ [Accessed 15 September 2011].

Thewiderenvironment/DG_070060

9. The Carbon Neutral Company, at: http://www.carbonneutral.com/pages/businesscanbenefit. asp

10. The target will be introduced progressively, rising from 75 per cent compliance in 2013 and 80 per cent in 2014 to 100 per cent in 2015.

\section{References}

Andreoni, J., 1990. Impure altruism and donations to public goods: a theory of warm-glow giving. The economic journal, 100 (401), 464-477.

Arrow, K., 2007. Global climate change: a challenge to policy. Economists' voice, June, 15. Bachram, H., 2004. Climate fraud and carbon colonialism: the new trade in greenhouse gases. Capitalism nature socialism, 15 (4), 5-20.

Barrett, S., 2007. Why cooperate? The incentive to supply global public goods. Oxford: Oxford University Press.

Berglund, C. and Matti, S., 2006. Citizen and consumer: the dual role of individuals in environmental policy. Environmental politics, 15 (4), 550-571. [245]

Boardman, B., 2007. Home truths: a low-carbon strategy to reduce UK housing emissions by $80 \%$ by 2050, ECI Research Report 34. Oxford: University of Oxford.

Brouwer, R., Brander, L., and Van Beukering, V., 2008. 'A convenient truth': air travellers' willingness to pay to offset their CO2 emissions. Climatic change, 90 (3), 299-313.

Bumpus, A. and Liverman, D., 2008. Accumulation by decarbonization and the governance of carbon offsets. Economic geography, 84 (2), 127-155.

Castree, N., 2003. Commodifying what nature? Progress in human geography, 27 (3), 273-297.

Chichilnisky, G. and Heal, G., 2000. Environmental markets: equity and efficiency. New York: Columbia University Press.

Cornes, R. and Sandler, T., 1996. The theory of externalities, public goods and club goods, 2nd ed. Cambridge: Cambridge University Press.

Dauvergne, P., 2010. Forum: the problem of consumption. Global environmental politics, 10 (2), 1-10.

Department of Energy and Climate Change, 2009. 2008 UK greenhouse gas emissions [online]. Available from: http://www.defra.gov.uk/environment/statistics/globatmos/index. htm [Accessed 17 October 2010].

Department of Energy and Climate Change, 2010. Renewable energy in 2010 [online]. Available from: https://restats.decc.gov.uk/cms/welcome-to-the-restats-web-site [Accessed 10 January 2011].

Department of Transport, 2009. Factsheets: UK transport and climate change data. Available from: http://www.dft.gov.uk/pgr/statistics/datatablespublications/energyenvironment/

climatechangefactsheets.pdf [Accessed 18 June 2010].

Ellerman, A.D., Convery, F.J., and Perthuis, C.d., 2010. Pricing carbon: the European Union emissions trading scheme. Cambridge: Cambridge University Press.

European Commission, 2008. European Commission, Directive 2008/101/EC of the European Parliament and of the Council of 19 November 2008 amending Directive 2003/87/EC so as to include aviation activities in the scheme for greenhouse gas emission allowance trading within the Community. Official journal L 00.

European Commission, 2009. EU action against climate change: leading global action to 2020 and beyond. Luxembourg: Office for Official Publications of the European Communities, 7.

European Commission, 2010a. Report from the Commission to the European Parliament, the Council, and the European Economic and Social Committee. Progress report on implementation of the community's integrated approach to reduce $\mathrm{CO}_{2}$ emissions from light-duty vehicles, $\mathrm{COM}$ (2010) 656 final. 
European Commission, 2010b. Communication from the Commission to the European Parliament, the Council, the European Economic and Social Committee and the Committee of the Regions. Analysis of options to move beyond $20 \%$ greenhouse gas emission reductions and assessing the risk of carbon leakage, COM (2010) 265 final.

European Commission, 2011. Commission implementing regulation (EU) No. 725/2011 of 25 July 2011 establishing a procedure for the approval and certification of innovative technologies for reducing $\mathrm{CO}_{2}$ emissions from passenger cars pursuant to Regulation (EC) No. 443/2009 of the European Parliament and of the Council, Official journal of the European Union, L 194/19.

EU, 2008a. Climate change and international security [online]. Available from: http:// www.consilium.europa.eu/uedocs/cms_data/docs/pressdata/en/reports/99387.pdf [Accessed 5 December 2011].

EU, 2008b. Report on the implementation of the European security strategy providing security in a changing world [online]. Available from: http://www.eu-un.europa.eu/documents/en/ 081211_EU\%20Security\%20Strategy.pdf [Accessed 5 December 2011].

Graham, V., 2007. Reality or rhetoric? Green tariffs for domestic consumers. London: National Consumer Council.

Helm, D. and Hepburn, C., eds., 2009. The economics and politics of climate change, Oxford: Oxford University Press.

HM Government, 2008. Climate change act 2008 [online]. London: The Stationery Office. Available from: http://www.opsi.gov.uk/acts/acts2008/pdf/ukpga_20080027_en.pdf [Accessed 10 June 2010]. [246]

HM Government, 2011. Climate change act 2008. HM Government, Carbon plan. London: The Stationery Office. Available from: http://www.legislation.gov.uk/ukpga/2008/27/ contents [Accessed 19 September 2012].

Hobson, K., 2004. Sustainable consumption in the United Kingdom: the 'responsible' consumer and government at 'arm's length'. The journal of environment and development, 13 (2), 121-139.

Intergovernmental Panel on Climate Change (IPCC), 2008. Climate change 2007: synthesis report. Geneva: IPCC.

Jagers, S.C. and Hammar, H., 2009. Environmental taxation for good and for bad: the efficiency and legitimacy of Sweden's carbon tax. Environmental politics, 18 (2), 218-237.

Jordan, A., 2010. Climate change policy in the European Union: confronting the dilemmas of mitigation and adaptation?. Cambridge: Cambridge University Press.

Kaul, I., Grunberg, I., and Stern, M., 1999. Defining global public goods. In: I. Kaul, I. Grunberg, and M. Stern, eds. Global public goods. International cooperation in the 21st century. New York: Oxford University Press, 2-27.

Kent, J., 2009. Individualized responsibility and climate change: 'if climate protection becomes everybody's responsibility, does it end up being No-one's'? Cosmopolitan civil societies journal, 1 (3), 132-149.

Kotchen, M.J. and Moore, M.R., 2005. Private provision of environmental public goods: household participation in green-electricity programs. Journal of environmental economics and management, $53(1), 1-16$.

Krahmann, E., 2008. Security: collective good or commodity? European journal of interna-tional relations, 14 (3), 379-404.

Krahmann, E., 2011. Beck and beyond: selling security in the world risk society. Review of international studies, 37 (1), 349-372.

Lane, B. and Potter, S., 2007. The adoption of cleaner vehicles in the UK: exploring the consumer attitude-action gap. Journal of cleaner production, 15 (11), 1085-1092.

Leander, A., 2005. The power to construct international security: on the significance of private military companies. Millennium, 33 (3), 803-826.

Loader, I., 1999. Consumer culture and the commodification of policing and security. Sociology, 33 


$$
\text { (2), 373-392. }
$$

Lohmann, L., 2009. Toward a different debate in environmental accounting: the cases of carbon and cost-benefit. Accounting, organizations and society, 34 (3 4), 499-534.

Lovell, H., 2005. Supply and demand for low energy housing in the UK: insights from a science and technology studies approach. Housing studies, 20 (5), 815-829.

Lovell, H., Bulkeley, H., and Liverman, D., 2009. Carbon offsetting: sustaining consumption?

Environment and planning A, 41 (10), 2357-2379.

MacKerron, G.J., et al., 2009. Willingness to pay for carbon offset certification and co-benefits among (high-)flying young adults in the UK. Energy policy, 37 (4), 1372-1381.

Maniates, M., 2001. Individualization: plant a tree, buy a bike, save the world? Global environmental politics, 1 (3), 31-52.

Mendez, R., 1999. Peace as a global public good. In: I. Kaul, I. Grunberg, and M.A. Stern, eds. Global public goods. international cooperation in the 21st century. New York: Oxford University Press, $382-417$.

Newell, P. and Paterson, M., 2010. The politics of the carbon economy. In: M.T. Boykoff, ed.

The politics of climate change. A survey. London: Routledge, 77-95.

O'Brien, K. and Leichenko, R., 2000. Double exposure: assessing the impacts of climate change within the context of economic globalization. Global environmental change, 10 (3), 221-232.

Ostrom, E., 2012. Nested externalities and polycentric institutions: must we wait for global solutions to climate change before taking actions at other scales? Economic theory, 49 (2), 353-369.

Paterson, M., 2000. Car culture and global environmental politics. Review of international studies, 26 (2), 253-270.

Pattie, K. and Crane, A., 2005. Green marketing: legend, myth, farce or prophesy? Qualitative market research, 8 (4), 357-370.

Paulsson, E., 2009. A review of the CDM literature: from fine-tuning to critical scrutiny? International environmental agreements, 9 (1), 63-80. [247]

Princen, T., Maniates, M., and Conca, K., eds., 2002. Confronting consumption. Cambridge, MA: MIT Press.

Prudham, S., 2009. Pimping climate change: Richard Branson, global warming, and the performance of green capitalism. Environment and planning A, 41 (7), 1594-1613.

Roberts, J.R., 1996. Green consumers in the 1990s: profile and implications for advertising. Journal of business research, 36 (3), 217-231.

Seyfang, G., 2005. Shopping for sustainability: can sustainable consumption promote ecological citizenship? Environmental politics, 14 (2), 290-306.

Stern, N., 2007. The economics of climate change: the Stern review. Cambridge: Cambridge University Press.

Stretton, H. and Orchard, L., 1994. Public goods, public enterprise, public choice. New York: St Martin's Press.

The Society of Motor Manufacturers and Traders, 2009. New car registrations [online]. Available from: http://www.smmt.co.uk [Accessed 21 September 2009].

Toke, D. and Lauber, V., 2007. Anglo-Saxon and German approaches to neoliberalism and environmental policy: the case of financing renewable energy. Geoforum, 38 (4), 677-687.

Wüstenhagen, R. and Bilharz, M., 2006. Green energy market development in Germany: effective public policy and emerging customer demand. Energy policy 34 (13), 1681-1696.

Note for citations: The in [] inserted figures note page breaks in the printed version. 